\title{
THE ROLES OF OTORITAS JASA KEUANGAN TO OVERCOME FICTIVE INVESTMENT BENGKULU CITY
}

\author{
Herawan Sauni ${ }^{1}$ \\ Dimas Dwi Arso ${ }^{2}$ \\ Faculty of Law Bengkulu University \\ ${ }^{1}$ Email : herawan.bk12017@gmail.com \\ ${ }^{2}$ Email : dimasdwiarso@gmail.com
}

\begin{abstract}
This research is purpose to know the role of Otoritas Jasa Keuangan in overcome fictitious investment in Bengkulu city and To know the efforts of Otoritas Jasa Keuangan to protect the consumers that take fictitious investment in Bengkulu city. This research uses empirical approach, that is research in the place by using interviews to get answers about the role of Otoritas Jasa Keuangan to overcome fictitious investment in Bengkulu city and the efforts of Otoritas Jasa Keuangan to protect consumers that has done fictitious investment in Bengkulu City. This research uses two types of data, that is primary data and secondary data. Then, its data to be analyzed in a research report that is qualitative descriptive. The results of the research is the role of Otoritas Jasa Keuangan to overcome fictitious investment in Bengkulu City that is preventive and repressive efforts. The preventive efforts for example to socializing and educating people to alert investment and coordinating with law enforcers and other regulators. The repressive efforts, for example set up an Alert Investment task force in every area. Then the efforts of Otoritas Jasa Keuangan to protect consumers that have fictitious investment in Bengkulu City is regulated in POJK Number 1 / POJK.07 / 2013 about Perlindungan Konsumen Sektor Jasa Keuangan.
\end{abstract}

Keyword:OJK, Fictive Investment, Protection.

\section{Introduction}

At the time, the citizen seems to be competing in investing, but not all institutions that raise funds from the citizen can be trusted as a place to safe invest. As it is known that investment is an activity undertaken in depositing or incorporating funds or money and capital to expect the benefits gained.

There are some people who argue that investing means wasting money or capital is not certain. Such an assumption may arise because of the risks to be faced when investing. Few people dare to invest if they see a big risk in investing. It is natural to have by everyone. because they feel they have been collecting money with difficulty just to give to something risky.

Investment risks that need to be attention are fraud, embezzlement, to fictitious investments. When the investment is criminal-related, the risk is to lose all 
investment funds. Realizing that investment is good but also risky, people are required to better understand investment products.

As for the reasons of someone in making an investment that is getting a profit, future needs, business needs, as a source of income, needs old time that safe, and investment is also easy to do.

Related to the rise of suspected fictitious investments in Indonesian territory, including Bengkulu, could result in many losses to the community. Lately, people in the city of Bengkulu many who invest in an institution called D4F (Dream for Freedom). As known, Monday (6/6) as many as 116 residents report to the Police Bengkulu because they feel they have become victims of this D4F. From the 116 victims report, estimated total loss reached $\mathrm{Rp} 1.8$ billion. Therefore, it needs to be analyzed about the existence of Otoritas Jasa Keuangan institution established based on Law Number 21 Year 2011 in conducting supervision and regulation on financial service institutions especially institutions that collect funds from the public in the field of investment.

How is the role of Otoritas Jasa Keuangan in overcome fictive investment in Bengkulu City? And How is the effort Otoritas Jasa Keuangan to protect consumers who have made fictive investments in Bengkulu City?

\section{Research Methodology}

This research is descriptive analysis. A descriptive study is intended to provide as much data as possible about humans, circumstances or other symptoms.

In this research will illustrate and analyze the role of Otoritas Jasa Keuangan overcome fictive investment in Bengkulu city and the efforts of Otoritas Jasa Keuangan in protecting consumers who have made fictive investments in Bengkulu City. This research uses an empirical approach, which is done by conducting research in the field by using direct interviews to obtain answers about the role of Otoritas Jasa Keuangan overcome fictive investment in the city of Bengkulu and the efforts of Otoritas Jasa Keuangan in protecting consumers who have made fictive investments in the city of Bengkulu

\section{Results and Analysis}

People are often easily tempted by the lure of investments that promise profits in a short time, but investment is one type of a lucky agreement. A lucky agreement means that people who make investments definitely do not earn a profit, but sometimes they also get a loss.

Seen from the juridical, then a lucky agreement such as investment should refer to the provisions contained in III Burgelijk Wetboek (BW) book on the engagement. Because, there is a commitment that comes from the agreement and from the Act. 
It remains to be remembered in our minds that not only is fictive investment a disservice to society, but there is also an umroh travel agency, First Travel which promises people that they will be able go umroh only by paying a very low cost compared to other umroh travel agencies. As a result of this action, more than a thousand people feel frauded because their expectations for umroh are not being realized while the money that has been paid to the Umrah travel agency is not returned.

Therefore, it is important to examine and analyze the roles of Otoritas Jasa Keuangan (OJK) overcome investment in Bengkulu and OJK's efforts in protecting consumers who have made fictive investments in Bengkulu.

With the existence of OJK, it is expected to support the interests of the national financial services sector so as to improve national competitiveness. In addition, OJK must also be able to safeguard the national interest such as : among others, human resources, management, control and ownership in the financial services sector, while taking into account the positive aspects of globalization. Otoritas Jasa Keuangan is established and based on sound governance principles, which include independence, accountability, transparency and fairness.

Otoritas Jasa Keuangan must have a structure with the principles of "checks and balances". This is manifested by a clear separation of functions, tasks, and regulatory and supervisory powers. The functions, duties and authority of arrangement and supervision shall be conducted by the Board of Commissioners through clear division of tasks for the achievement of the objectives Otoritas Jasa Keuangan. The duties of members of the Board of Commissioners include the areas of duties related to the code of ethics, internal control through audit board mechanisms, education and consumer protection, as well as functions, duties and supervisory powers for the sectors of Banking, Capital Market, Insurance, Pension Funds, Financing Institutions and Financial Services Institutions Others

Based on the authors' interviews with representatives of OJK of Bengkulu Province namely the field of education and consumer protection, that in the investment does not recognize the term fictive investment but illegal investment. Therefore, business entities that receive contributions from the community are not fictitious business entities, but illegal business entities. Business entities are said to be illegal, because they have not obtained official permission from OJK and other authorities. If this entity is left without any action, then public trust to a business entity that moves by receiving contributions from the public will be reduced and can disrupt financial stability.

The role of OJK overcome this illegal investment is not mentioned explicitly in 
Law No. 21 Year 2011. When considered, contained in the OJK Law only regulates the protection of consumers and the public when harmed by financial institutions, in which case OJK only take action when a complaint from disadvantaged citizen. Though the problem of illegal investment is very detrimental to consumers, so OJK must act decisively

Parties that offer illegal investments are mostly non-financial institutions so they are not registered and overseen by OJK. OJK participates against illegal investment offer that harm society through effort:

1. Preventive: socialize and educate investment alert and coordinate with law enforcers and other regulators.

2. Repressive: facilitation of dispute settlement, cessation and other activities, establishing Alternative Dispute Settlement Institutions (LAPS), and establishing Investment Alert Task Force in all regions.

The Investment Alert Task Force (SWI) was established based on the Decree of the Board of Commissioners of OJK Number 01 / KDK.01 / 2017 dated January 1, 2017 on the Establishment of Task Force on the Suspect of Legal Action in the Field of Community Funds and Investment Management which consist of OJK, RI, Ministry of Trade, Ministry of Communication and Informatics, Ministry of Communication and Informatics, and BKPM.

The purpose of the Investigation Task Force is to raise awareness and protection to the public against potential losses resulting from public fund raising and investment management by irresponsible parties, it is necessary to prevent and handle alleged unlawful actions in the field of fund raising and investment management in a coordinated way and integrated by the Ministries / Agencies and / or other relevant agencies. The main tasks of the Investment Alert Task Force are:

a. Education and socialization to the community

b. Improve case handling coordination

c. Inventory cases of alleged illegal investments that have the potential to harm the community

d. Analyze cases, and identify authorized agencies to handle them

e. Conduct a joint examination and follow-up to stop the case

f. Stopping or blocking the rampant case

The work program of the SWI is covering

prevention and treatment programs. Prevention programs include education and monitoring of potential illegal investments, while handling programs include:

a. Call Center (1500655) and email Task Force Investment (waspadainvestasi@ojk.go.id)

b. Coordination between institutions incorporated in the Task Force Investments

c. Joint examination to obtain data or information directly to the parties suspected of illegal investment activities

d. Periodic coordination meetings every 2 (two) months and / or incidental

e. Prepare recommendations for handling illegal investments by law enforcement. 
SWI is authorized to handle illegal investment cases. Communities who are victims of this illegal investment can report to the SWI, so that it can then be followed up with legal process. Nationally, there are some business entities that do not have permission from OJK and other authorities but receive funds from the public. Whereas a permit is a fundamental instrument for establishing a business entity, even more so when its business is based on community contributions.

Here is the data of recapitulation of complaint handling and / or 2016 question:

a. Number of complaints: 210

b. Number of complaints perentitas: 121

c. Number of complaints followed: 31

d. Number of complaints (entering legal process): 4

The business entities are declared as illegal investment business entity namely:

1. PT Compact Sejahtera Group, Compact 500 or Bintang Abadi Sejahtera

Cooperative or ILC.

This business entity is led by Anton

Setiawan, with the address of Cicadas

Highway, RT / RW: 001/003, Cicadas,

Gunung Putri, Kab. Bogor, West Java.

Operating mode is:

a. Payments are on time and "No Zonk".

b. Owner is clear and always work for the continuity of the system.

c. Can not Hit and Run.

d. "Profit Help" earns 25\% per month and sponsorship bonus of $5 \%$.

e. Have a cash reserve fund dibank.

f. It's been over a year.

g. Paying the initial investment package ranges from Rp.500.000, - s / d Rp.100.000.000, -
The things that have been done to watch

the investment task force are:

a. On September 22, 2016, Task Force Investment has held a discussion meeting with the Board of Directors of PT Compact Sejahtera Group related to the legality of business activities.

b. On November 10, 2016, pursuant to the result of the meeting of September 22, 2016, PT Compact Sejahtera Group has submitted a statement stating that it has suspended all its activities because it is not in accordance with the permit held. Currently PT Compact Sejahtera Group has become Koperasi Bintang Abadi Sejahtera.

\section{PT Inti Benua Indonesia.}

This business entity is led by Pablo Putera Continent. BMP. SH, with the address of Jalan M. Yusuf Raya I. Kav. 38A. Sukmajaya, Depok, West Java. The operating mode is:

a. Prospective customers who want to own a vehicle must first pay an administrative fee (for a car of $\mathrm{Rp}$ $5,000,000$ and for motorcycles of $\mathrm{Rp}$ $750,000)$, then fill out the unit order form and the completeness of personal data.

b. Then the prospective customer, must pay a deposit of $54 \%$ of the price of the desired vehicle OTR and signed the contract HGP IBIS.

c. Each year must pay a deposit (for cars of $10 \%$ and for the motor of $15 \%$ the maximum period of time given once a three-year contract.

d. At the end of the contract for three years, the car is refunded and the deposit funds are returned but deducted $10 \%$. However, for motorcycles, motorcycles are returned and deposit funds are refunded but cut $15 \%$ or become proprietary by increasing the cost of $15 \%$. 
The things that have been done are alert investment task force, namely:

a. On October 5, 2016, Task Force Investments invited PT Inti Benua Indonesia to explain the products and business processes of PT Inti Benua Indonesia. However, the directors of PT Inti Benua Indonesia were not present.

b. On October 31, 2016, Task Force Investments has invited again and the directors of PT Inti Benua Indonesia are not present.

c. Activities undertaken by PT Inti Benua Indonesia are activities that resemble those of a financing institution so that a permit is required to perform such activities.

\section{PT Inlife Indonesia}

This business entity is headed by Wahyu

Kusumo Aribowo, having its address at $\mathrm{J} 1$

Mega Kuningan Lot 5.1, Rajawali Tower,

East Kuningan, Setia Budi South Jakarta.

The operating mode is:

a. Inlife Investment is an investment program with a minimum capital of Rp.1.000.000, - within a period of seven days with a commission of 15 $25 \%$, received every seven days by $15 \%$ plus initial fund and will be directly transferred to customer's account. Thus, the total fund to be received within a period of seven days is Rp.1.150.000, -

b. InLife's Investment Profit manages funds in three business areas: Stocks, Mutual Funds, Bonds and Money Market (in cooperation with several foreign companies), Housing, Commercial and Land Kavlingan, Precious Metals, Forex, Exports and Imports.

c. PT Inlife Indonesia on its website has included logo, Financial Services
Authority, Bappebti, Bapepam-LK, and Investment Coordinating Board (BKPM) without permission. In addition, mentioned that PT Inlife Indonesia obtained the operating license from Bapepam-LK.

The things that have been done to watch the investment task force are:

a. On November 29, 2016, Task Force Investment invited Board of Directors meeting of PT Inlife Indonesia to be able to clarify related to the legality of business activity. However, the Directors of PT Inlife Indonesia did not attend the meeting.

b. Based on information obtained by Task Force Investments, PT Inlife Indonesia is not registered in OJK, Bappebti or BKPM.

4. Bermuda Triangle Cooperative / Profitwin77.

This business entity is led by H. Syamsul Umar who is located at Ruko Citraland, Block L / 22, Gowa, South Sulawesi. The operating mode is:

a. ProfitWin77 is part of Gilang Gemilang Group (GGG) based in Makassar. GGG business consists of: Triangle Cooperative bermuda, Profitwin77, and shopping 77.

b. Registration fee Rp. 150.000, -.

c. New members are required to purchase an investment package of at least US \$ 100 , the larger the bonus investment package the more seirng given (every day until every 10 days).

d. Passive members will benefit 2\% (two percent) per day for 100 calendar days.

e. Active members will earn daily bonuses and sponsor bonuses when recruiting new members.

f. The processing of investment funds comes from members.

Things that have been done alert watchgirl investment On September 29, 
2016, Task Force Investments has invited the Bermuda Triangle Cooperative meeting to be able to clarify the legality of business activities cooperatives. However, the board of the Bermuda Triangle Cooperative was not present at the meeting's invitation.

\section{PT Cipta Multi Business Group}

This business entity is headed by Fitriyani as a director and Akh. Turmidi as commissioner having address at Jalan Raya Ancol RT / RW: 006/002, Ex. Sukamanah, Sindangkasih Sub-district, Ciamis Regency, West Java. Its business activities are Supplier of toll road construction materials, apartment financing, remittances, and financing of vehicle sales and has collected 1,700 (one thousand seven hundred) investors. The amount of funds collected amounted to more than Rp850.000.000. Of the above members, about 400 investors have finished their investment contract period with PT Cipta Multi Bisnis Group. The Operating Mode is:

a. Profit sharing of $30 \%$ of the initial capital per month to investors with the following conditions:

b. Capital minimum Rp500.000;

c. Contract for 6 months; and

d. The initial capital is fully returned to investors in the seventh month.

e. The referral bonus of $4 \%$ for every first, second, third, and so on. Specifically for investments above Rp100.000.000 will receive fee $2 \%$ and above Rp500.000.000 will receive fee $1 \%$.

The things that have been done are alert investment task force, namely: a. On December 27, 2016, Task Force Investment has invited the Board of Directors of PT Cipta Multi Business Group to explain the legality and business activities undertaken. In the meeting, the Director and Commissioner of PT Cipta Multi BusinessGroup explained the business process and legality of the company to the Investigation Task Force.

b. Based on the 27 December 2016 meeting, the Director and Commissioner of PT Cipta Multi Bisnis Group made a statement stating that:

c. Stopping all community fundraising activities and not recruiting members again starting December 27, 2016 because they do not have permission in accordance with applicable laws and regulations.

d. Ask all people to be able to know this statement and be careful when there is a similar offer on behalf of PT Cipta Multi Business Group that raise funds.

e. Returns all funds collected from PT Cipta Multi Bisnis Group investors no later than 28 February 2017.

f. In the event that PT Cipta Multi Bisnis Group conducts public fundraising activities before obtaining permission from the competent authority, Fitriyani and Turmidi are willing to be prosecuted by law enforcement officers

\section{UN Swissindo.}

UN Swissindo is a world organization and Consortium Internationally Swissindo World Trust International Orbit (12 Selection Organization). The world representative office in Laos country (Laos P.D.R) and chaired by Chairman. Sino Soegihartonotonegoro, St-Mi. As one of the world's institutions claiming to have waived its financial rights at Bank Indonesia and 6 
(six) Prime Bank (BCA, Bank Mandiri, BRI, BNI, Lippo Group / CIMB and Bank Danamon) for $\$ 6.1 \mathrm{~T}$ to free people debts Indonesia since February 4, 2016. The operating mode is:

a. UN Swissindo has declared and report have certificate of release of debt for and to TNI-POLRI and all Indonesian people;

b. UN Swissindo World trust International Orbit as the holder of Bank Indonesia Certificate (SBI) Account Owner at 6 Prime Bank SKRBINo: 0126-BISKR / XI / 2012 dated November 1, 2012 and SKR / IDR00013 dated March 3, 2012 approved by the International Association of British Royal Families Control No. 01302014-CO300 dated 31 January 2014;

c. That with the certificate for all Indonesian people using rupiah currency in the banking system (BCA, BRI, BNI, Mandiri, Danamon, Lippobank, CIMB Niaga and all leases are exempt from all debt burden since it has been paid by UN Swissindo;

d. Requirements to become a member of UN SWISSINDO is a society that has Debt / Receivable at PT.FINANCE by providing Photo Copy of ID card, 3x4 Color Photo Pass (1 sheet) and Cash Rp.200.000,00.

Anticipatory steps taken by OJK are:

a. Socialize to all community, financial service and finance company such as:
1) The
certificate
originated fromUNSWISSINDO is Fake.
2) BI Governor DARMIN

NASUTION never signed SBI Certificate dated June 26, 2012 with value Rp.4.500.000.000.000.000,00 (four thousand five hundred trillion).

3) BI never receives money from UN SWISSINDO.

4) If the public, the Financial Services and Finance Companies receive / know about similar information to immediately report to the nearest law enforcement apparatus.

5) Clarification and checks have been made at 6 (six) Prime Banks, there is no SBI fund of USD 6.1 claimed by Swissindo to repay the debt of Indonesian people

b. To the investigator:

1) Against Certificate of Bank Indonesia Certificate (SBI) to be Scientific Identification to Forensic Laboratory of Criminal Investigation Police to know original / not Certificate.

2) Requested information from $B I$ Governor Darmin Nasution and OJK Commissioner Chairman Muliaman Dhadad to ascertain whether ever signed the certificate.

3) To facilitate Asset Tracing on the results of the investigation so that investigators apply the TPPU (money laundering crime).

If in Bengkulu, a very public-purpose case is about investments made by D4F (Dream For Freedom) under the leadership of Fili Muttagien. Quoted from the daily Rakyat Bengkulu, losses reached 3 bln rupiah, which is the biggest loss in the city of Bengkulu. OJK has also clarified that D4F is an entity that is not registered in OJK and not under the supervision of OJK to conduct investment activities in Indonesia. This means that since its establishment, the D4F has not obtained any license from OJK to receive funds from the public in the form of investment. Therefore, then OJK Bengkulu Province often socialize to the public to be more careful to invest their funds.

The main characteristic of fraud under the guise of investment is the absence of legal 
licensing documents from government agencies, regulators / supervisors related to financial services and investment, although it has the documents deed of incorporation with the legality of business in the form of trading business license and sign the list of companies. Whereas the Government Regulation clearly stipulates that companies are prohibited from using SIUP to conduct activities to raise public funds by offering an unreasonable profit pledge.

There are several articles in the Criminal Code which may entrap the perpetrators of illegal inves- tigations, for example in relation to embezzlement under Article 372 of the Criminal Code with a maximum imprisonment of 5 years and fraud stipulated in Article 378 of the Criminal Code for 4 years. Then in Article 46 paragraph (1) of Law Number 10 Year 1998 regarding the Amendment of Act No. 7 of 1992 concerning Banking stating that the collection of public funds in the form of deposits without business license from OJK shall be subject to 5 years imprisonment and most 15 years old and a fine of at least Rp 10 billion and a maximum of Rp 20 billion. In fact, if undertaking capital market activities without OJK license, then based on Article 103 (1) Law Number 8 of 1985 concerning Capital Market shall be subject to a 5 year old long-term penalty crime and dendapaling of Rp 5 billion.
OJK Bengkulu Province then conduct an evaluation, whether it is related to the duty of prevention and with the task of handling. Assessment indicators related to prevention tasks are the amount of community involvement in illegal investments declining, increasing public awareness of legal and illegal investments, and referring to the results of a survey of educational practices in the rampant areas of illegal investment. While the assessment indicators related to the task of handling that is based on the existence of reports of violations of regulations found by each member Task Force Investments to law enforcement.

With the establishment of the Investment Alert Task Force and the Local Government Investigation Task Team, the prevention and handling of alleged unlawful actions in the field of public fund raising and investment management can be effectively implemented in order to provide protection to consumers of the financial services sector and increase public confidence in the financial industry.

The rise of illegal investment makes consumers wary when transferring their funds to invest, because consumers need to be more careful to see what kind of business entities that lola their investment funds. Often, Business Entities promise high interest or returns to consumers when investing in their business entities. Therefore, consumers should be suspicious if investment products that promise interest or 
high yield. Then, the consumer must be smart and conscientious about the permit on the business entity, whether there has been a permit issued by the Financial Services Authority or other authority.

Consumers sometimes do not notice that the company that sells the investment products in secret or non-transparent, the truth or validity of the offered investment products, the interest or yield of the offered products with interest offered by the bank or the capital market, whether or not the market. Therefore, the government has provided a variety of ways to secure investment for consumers, although investment often also contains risks. For investment in real sector, can be through direct investment scheme, profit sharing, franchise, and joint venture. For investment in financial markets, can be through banking, insurance, or capital markets. With investments in banks or non-bank financial institutions, the funds of customers or communities invested are more protected because:

Banks and non-bank financial institutions are established and operate on the permission of the regulator and the government.

In its operations, banks and nonbank financial institutions always adhere to applicable laws or regulations. Regulators and governments always oversee the operations of banks and non-bank financial institutions that ensure their operations remain in compliance with prevailing beacons. When referring to the OJK Law, the protection of consumers and the public is regulated in Chapter VI Articles 28 - 31.

Article 28 reads for the protection of Consumers and the public, OJK is authorized to undertake Consumer and Community harm prevention measures, which include:

a. provide information and education to the public on the characteristics of the financial services sector, services and products;

b. ask the Financial Services Institution to cease its activities if such activities have the potential to harm the public; and

c. other actions deemed necessary in accordance with the provisions of the laws and regulations in the financial services sector.

Article 29 reads OJK conducting Consumer complaints services which include:

a. prepare adequate equipment for Customer complaints services harmed by actors at the Financial Services Institution;

b. making the complaints mechanism of the Customer harmed by the perpetrator of the Financial Services Institution; and

c. facilitate the settlement of complaints Consumers harmed by actors in Financial Services Institutions in accordance with the laws and regulations in the financial services sector.

Article 30 paragraph (1) reads for the protection of Consumers and the public, OJK is authorized to conduct legal defense, which includes: 
a. order or perform certain actions to the Financial Services Institution to resolve complaints of the Customer harmed by the said Financial Services Institution;

b. filed suit:

1. to recover the property of the disadvantaged party from the party causing the loss, whether it is under the control of the party causing the loss in question or under the control of the other party in bad faith; and / or

2. to obtain indemnification from the party causing loss to the Consumer and / or Financial Services Institution as a result of violation of the laws and regulations in the financial services sector.

Article 30 paragraph (2) Indemnification as referred to paragraph (1) letter b number 2 shall only be used for the payment of compensation to the injured party. The OJK Law Article 31 mandates that OJK need to enact the OJK Regulation concerning Consumer Protection of Financial Services Sector. For this reason, OJK then issues the Regulation of Otoritas Jasa Keuangan Number 1 / POJK.07 / 2013 about Perlindungan Konsumen Sektor Jasa Keuangan.. To improve consumer protection and public trust to the financial industry, OJK needs to take preventive, curative or repressive actions through the formation of the Investment Alert Task Force.

Unlicensed public fund raising activities are happening in the regions and need to be optimized and efficient and quick response to complaints and / or reporting from the community, then OJK also established the Working Team of Local Investment Task Force.

OJK has the main duty of arranging and conducting activities in the field of education, and consumer protection, including developing policies and programs to encourage financial inclusion, complaint services, settlement of financial disputes, legal defense and consumer protection by promoting the principles of efficiency and effectiveness, fairness and independence, and encourage accessibility of services.

Education and consumer protection is an effort to increase understanding of society and consumers about the various institutions, products and financial services that aims to improve access, use and trust of society and consumers to institutions and financial services products in Indonesia in order to improve the welfare of the community. The importance of consumer protection efforts as it is a fundamental requirement in addressing the globalization of financial systems and the rapid advancement of information technology, which creates the complexity of financial products and / or services, so consumers should:

1. Understand the benefits, costs, and risks of the product and / or financial services.

2. Understand products and / or services to avoid fraud, misuse and irregularities.

3. Understand the rights and obligations

4. Reducing potential disputes 
5. Know where to go and what to do in case of dispute.

For the curative role of OJK, OJK Act has also been accommodating for it. Because the OJK is given the role of legal defense to the consumer by filing a lawsuit to recover the property of the disadvantaged party from the party causing the loss, either under the control of the party causing the intended loss or under the control of the other party in bad faith. Therefore, it is hoped that OJK can conduct legal defense so that consumer's money can be returned

In Article 22 of the Financial Services Authority Regulation Number 1/ POJK.07 / 2013 concerning Consumer Protection of the Financial Services Sector shall be regulated concerning the standard agreement between the financial services and consumer business actors. However, the default agreement is prohibited if there is an exoneration clause. The prohibited exoneration clause shall mean declaring the transfer of responsibility or liability of the financial services business actor to the consumer and stating that the Financial Services Businesses shall be entitled to refuse refunds paid by the Consumer on purchased products and / or services.

Consumer complaints constitute a fundamental instrument in law enforcement in the field of illegal investment. Based on Article 40 paragraph (1), POJK No. 1 Year 2013, the consumer may submit a complaint indicating a dispute between the business actors of financial services with the consumer to the financial services authority. Therefore, OJK then appoints the facilitator to carry out the complaint resolution function.

POJK No. 1 of 2013 also regulates the sanctions. In Article 53, Sanctions for business actors of financial services and / or parties violating the provisions in the Regulation of the Financial Services Authority shall be liable to administrative sanctions in the form of:

a. Written warning;

b. The penalty is the obligation to pay a certain amount of money;

c. Restrictions on business activities;

d. Suspension of business; and

e. Revocation of business activity permit.

Therefore, a business entity proven to conduct business in the field of illegal investment may be subject to sanctions by OJK, even the head of the business entity may also be subject to criminal sanctions

\section{Conclusion}

Based on the results of research conducted by the author with the title "The Role of Otoritas Jasa Keuangan Overcome Fictive Investment In Bengkulu City", it can be concluded that The role of Otoritas Jasa Keuangan overcome fictive investments in the city of Bengkulu such as preventive and repressive efforts. Preventive measures such as socializing and educating investment alert and coordinating with law enforcers and 
other regulators. Then repressive efforts, such as forming the Investment Alert Task Force in all regions.

Efforts of Otoritas Jasa Keuangan to protect consumers who have made fictive investments in Bengkulu City are regulated in the Financial Services Authority Regulation No. 1 / POJK.07 / 2013 on Consumer Protection of the Financial Services Sector. The regulation stipulates that OJK has appointed facilitator to perform complaint settlement function from consumer, so that complaints from consumers can be followed up by sanctioning a business entity proven to conduct business in the field of illegal investment.

As for suggestions that can be given by the author, the OJK is expected to conduct legal defense to protect consumers in the form of filing a lawsuit to recover property owned by the injured party from the party causing the loss, either under the control of the party causing the intended losses or under the mastery of others in bad faith.

\section{Bibliography}

Bambang Murdadi. (2012) Otoritas Jasa Keuangan (OJK) Pengawas Lembaga Keuangan Baru yang Memiliki Kewenangan Penyidikan. Semarang : Universitas Muhammadiyah.

Iswi Hariyanti dan R. Serfianto. (2010) Buku Pintar Hukum Bisnis Pasar Modal. Jakarta : Visimedia.
Kurniawan. (2011) Hukum Perlindungan Konsumen. Malang : UB Press.

Nindyo Pramono. (2013) Hukum PT Go Public dan Pasar Modal. Yogyakarta : Andi.

Ridwan Khairandy. (2010). Hukum Pasar Modal. Yogyakarta : FH UII Press.

Satuan tugas penanganan dugaan tindakan melawan hukum di bidang penghimpunan dana masyarakat dan pengelolaan investasi, Meningkatkan peran dan partisipasi publik dalam mencegah investasi ilegal,Bahan Seminar, 28 Februari 2017, Bengkulu.

Sentosa Sembiring. (2012). Hukum Perbankan, Bandung : Mandar Maju.

Surjono Soekanto. (1986). Pengantar Penelitian Hukum. Jakarta : UI Press.

Zaeni Asyhadie. (2005). Hukum Bisnis. Jakarta : Raja Grafindo Persada.

www.harianrakyatbengkulu.com 